\title{
Effect of reactive oxygen species on cholinergic receptor function
}

\author{
A. Venkatesham, P. Sharath Babu, J.Vidya Sagar, D. R. Krishna
}

Cancer, Aging and Metabolism Research Division, University College of Pharmaceutical Sciences, Kakatiya University, Warangal - 506009 , Andhra Pradesh, India.

Received: 24.4.2004

Revised: 16.12 .2004

Accepted: 24.2.2005

Correspondence D.R. Krishna E-mail: krishna@ucpsci.org

\begin{abstract}
Objective: To investigate the role of reactive oxygen species (ROS) on cholinergic receptor function.

Materials and Methods: Rectus abdominis and isolated heart preparations of frog (Rana tigirina) were used to assess nicotinic and muscarinic receptor activity, respectively. Thirty percent hydrogen peroxide $\left(\mathrm{H}_{2} \mathrm{O}_{2}\right)$ solution and Fenton mixture $(\mathrm{Fm}, 13.9 \mathrm{mg}, 50 \mu \mathrm{M}$ of $\mathrm{FeSO}_{4}, 75 \mathrm{mg}$ of sodium EDTA and $50 \mu \mathrm{L}$ of $30 \% \mathrm{H}_{2} \mathrm{O}_{2}$ were added to $10 \mathrm{ml}$ of $0.1 \mathrm{M}$ $\mathrm{K}_{2} \mathrm{HPO}_{4}$ ) were used to generate $1 \mathrm{mM} \mathrm{H}_{2} \mathrm{O}_{2}$ and hydroxyl free radicals. The responses were recorded with acetylcholine at different phases of exposure of tissues to ROS. Normal frog Ringer was used as a physiological solution. Responses of acetylcholine were also recorded in the presence of ROS before and after exposure of the tissue to an antioxidant (ascorbic acid).

Results: Free-radical-mediated receptor damage was dose (1-100 $\mathrm{mM} \mathrm{H}_{2} \mathrm{O}_{2}$ ) and time (10-30 min) dependent when responses were taken with $30 \mu \mathrm{g}$ and $30 \mathrm{ng}$ of ACh for nicotinic and muscarinic receptors, respectively. There was no effect of ROS on prior exposure of tissue to ascorbic acid (antioxidant) at a concentration of $300 \mu \mathrm{g} / \mathrm{ml}$. The antioxidant has not shown any beneficial effect on sulfhydryl groups of G-protein-coupled muscarinic receptors, which are more susceptible and sensitive to ROS than ionchannel nicotinic receptors where there is $96 \%$ protection with the antioxidant. Reactive oxygen species has shown different effects on receptor function.

Conclusion: Free radicals continuously cause considerable damage to the receptors. Gprotein-coupled muscarinic receptors are more susceptible than ion-channel-linked nicotinic receptors. Antioxidants are shown to play a major role in protecting free-radicalmediated receptor damage.
\end{abstract}

KEY WORDS: Antioxidants; free radical; acetylcholine; ascorbic acid.

\section{Introduction}

Receptors are specialized to recognize and respond to individual signaling molecules with great selectivity. Proteins, glycoprotein, proteolipids, and associated proteinaceous matter constitute receptors. ${ }^{[1]}$ Free radicals are chemical species possessing an unpaired electron that can be considered as a fragment of molecules which are generally very reactive. They are produced continuously in cells either as accidental by-product of metabolism or deliberately during phagocytosis. Reactive oxygen species (ROS) includes not only oxygen free radicals (OFR) but also nonradical oxygen derivatives that are involved in oxygen radical production. Hydrogen peroxide $\left(\mathrm{H}_{2} \mathrm{O}_{2}\right)$ easily breaks down, particularly in the presence of transition metal ions to produce the most reactive OFR, the hydroxyl radicals.
Oxygen-derived free radicals and other reactive oxygen species have been shown to be important mediators of cellular and tissue injuries in a variety of diseases such as diabetes, heart failure, hypertension, and ischemia/reperfusion. Further, ROS are mediators of lipid peroxidation, protein and nucleic acid modification, which can result in altered cellular responses and cell death. ${ }^{[2]}$ It has been recognised that free radicals are involved in the etiology of many diseases. Although insight into the role of free radicals in physiology and pathogenesis has been gained over the recent years, remarkably little knowledge exists on the effect of free radicals on receptormediated response..$^{[3]}$

Imbalance between production of OFR and antioxidant defense can result in oxidative stress leading to metabolic impairment and cell death. Oxidative stress may be due to deficiency of antioxidants (such as glutathione, ascorbate or 
$\alpha$-tocopherol), antioxidant enzymes [superoxide dismutase (SOD), catalase, glutathione peroxidase] and/or from increased levels of OFR. ${ }^{[4]}$ Several definable diseases arise from disorders in receptors or receptor-effector systems, such as feminization syndrome, generalized endocrinopathy and pseudohypoparathyrodisim type 1a. ${ }^{[5]}$ Nicotinic receptors in myasthenia gravis, ${ }^{[6]}$ LDL receptors in familial hypercholesterolemia, $V_{2}$ receptors in nephrogenic diabetes insipidus, ACTH receptors in cortical insufficiency, PTH receptors in pseudohypoparathyroidism and $B$-adrenoceptors in hypertensive states are implicated in the free radical damage of receptors. ${ }^{[7]}$

The generation of ROS has been observed under various pathological conditions. In rat atria exposed to ROS, adrenoreceptor stimulation reduces the contractile force as a result of a protein kinase $\mathrm{C}$-mediated $\mathrm{Na}^{+} / \mathrm{K}^{+}$-ATPase activation. ${ }^{[8 \mid}$ Activation of the $M_{1}$ muscarinic receptor subtype in rat pheochromocytoma cells stably expressing cloned $\mathrm{M}_{1}$ muscarinic acetylcholine receptors was previously shown to induce morphological changes and growth arrest. However, signalling pathways, which led to these effects, were not identified. ${ }^{[9]}$

So far, the influence of ROS on the cardiac muscarinic receptors has not been studied in detail. The only studies so far performed indicate that the free radicals and $\mathrm{H}_{2} \mathrm{O}_{2}$ can alter the binding characteristics of the cardiac $\mathrm{M}_{2}$ receptor, while the functional data are not yet available. ${ }^{[10]}$ Reactive oxygen species act as second messengers in muscarinic-induced cellular signalling. Moreover, generation of ROS appears to be an early and critically intermediary event, which occurs immediately after stimulation of the muscarinic receptor and in turn affects the muscarinic-mediated cellular signalling. ${ }^{|9|}$ Thus, receptors are prone to be damaged by the effects of free radicals. Even the pathogenesis of free-radical-mediated receptor dysfunction on cholinergic receptors is not well defined. In the present study, an attempt has been made to study these effects in vitro.

\section{Materials and methods}

\section{Drugs and their source}

Ferrous sulfate $\left(\mathrm{FeSO}_{4}\right)$, sodium EDTA, dipotassium hydrogen orthophosphate $\left(\mathrm{K}_{2} \mathrm{HPO}_{4}\right), \mathrm{H}_{2} \mathrm{O}_{2}$ and ascorbic acid (AA) were purchased from SD. Fine Chemicals, Mumbai, India. Acetylcholine was procured from LOBA Chemie Co., Mumbai, India. The chemicals required for the preparation of frog Ringer were purchased from SD. Fine Chemicals, Mumbai, India. All chemicals used were of analytical grade.

\section{Preparation of solutions}

Fenton mixture $(\mathrm{Fm})$ : The method of preparation of $\mathrm{Fm}$ is similar to that reported earlier. ${ }^{[11]}$ About $13.9 \mathrm{mg}$ ferrous sulfate $7 \mathrm{H}_{2} \mathrm{O}, 75 \mathrm{mg}$ of sodium EDTA and $50 \mu \mathrm{l}$ of $30 \% \mathrm{H}_{2} \mathrm{O}_{2}$ were added to $10 \mathrm{ml} 0.1 \mathrm{M}$ dipotassium hydrogen orthophosphate solution and the reaction mixture was kept in a water bath at $40^{\circ} \mathrm{C}$ for 20 min with continuous stirring and the solution was used as a source of hydroxyl free radicals.

Frog Ringer solution: The physiological salt solution was prepared by adding $\mathrm{NaCl} 110 \mathrm{mM}, \mathrm{KCl} 1.9 \mathrm{mM}, \mathrm{CaCl}_{2} 1.1 \mathrm{mM}$, $\mathrm{NaHCO}_{3} 2.4 \mathrm{mM}$, and Glucose $11.1 \mathrm{mM}$ in distilled water.

Acetylcholine solution: The stock solution of acetylcholine was prepared in $5 \% \mathrm{NaHPO}_{4}$ solution so as to contain $10 \mathrm{mg} /$ $\mathrm{ml}$ and it was stored at $-4^{\circ} \mathrm{C}$. Serial dilutions of $1 \mathrm{mg} / \mathrm{ml}$, $100 \mathrm{mg} / \mathrm{ml}, 10 \mathrm{mg} / \mathrm{ml}, 1 \mathrm{mg} / \mathrm{ml}$, and $100 \mathrm{ng} / \mathrm{ml}$ were prepared from the stock solution at the time of the

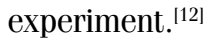

Effect of free radicals on nicotinic and muscarinic receptor function

Effect of ACh in the presence of $100 \mathrm{mM} \mathrm{H}_{2} \mathrm{O}_{2}$ and hydroxyl free radicals on frog rectus abdominis (FRA): Frog (Rana tigirina) was pithed and the rectus abdominis muscle was dissected as thin as possible and placed in a petri dish containing frog Ringer solution. A small piece of the above tissue was mounted in an isolated organ bath containing frog Ringer's solution at room temperature. The tissue was maintained under a constant load of $1 \mathrm{~g}$ in $10 \mathrm{ml}$ organ bath. It was equilibrated for 30 min with regular change of bath fluid every 10 min. ${ }^{13]}$ Dose response was recorded on the kymograph. After stabilization period of $10 \mathrm{~min}$, the Ringer solution was replaced with Ringer solution containing ROS $100 \mathrm{mM} \mathrm{H} \mathrm{H}_{2}$ or Fm and each tissue was bathed for 10 min following which the submaximal dose response was recorded. In the same tissue, Ringer solution containing ROS was replaced with normal frog Ringer solution and submaximal dose response was recorded.

Effect of pretreatment with AA (antioxidant) on ACh in the presence of $100 \mathrm{mM} \mathrm{H}_{2} \mathrm{O}_{2}$ and Fm on FRA: The dose response curve was taken in the presence of frog Ringer solution containing AA $(300 \mu \mathrm{g} / \mathrm{ml})$ after remaining in contact with the muscle for $10 \mathrm{~min}$. After that, the frog Ringer solution containing AA was replaced with Ringer solution containing $100 \mathrm{mM} \mathrm{H} \mathrm{H}_{2} \mathrm{O}_{2}$ or Fm. The rectus abdominis muscle was bathed in the above-mentioned solution for $10 \mathrm{~min}$. Then, the responses were recorded.

Effect of ACh in the presence of $100 \mathrm{mM} \mathrm{H}_{2} \mathrm{O}_{2}$ followed by treatment with AA on FRA: The dose response curve was recorded in normal frog Ringer solution. After that, the frog Ringer solution was replaced with frog Ringer solution containing $100 \mathrm{mM} \mathrm{H} \mathrm{H}_{2} \mathrm{O}_{2}$ and the rectus abdominis muscle was bathed in the above-mentioned solution for $10 \mathrm{~min}$ and the responses were recorded. Then, the above solution was replaced with frog Ringer solution containing AA and responses were recorded.

Effect of ACh diluted in $100 \mathrm{mM} \mathrm{H}_{2} \mathrm{O}_{2}$ and $\mathrm{Fm}$ on FRA: The dose response curve was recorded on FRA with ACh diluted in frog Ringer solution, $100 \mathrm{mM} \mathrm{H}_{2} \mathrm{O}_{2}$ and Fm separately and compared with dilutions of ACh in frog Ringer solution.

\section{Effect of free radicals on muscarinic receptor function}

Effect of ACh in the presence of $1 \mathrm{mM} \mathrm{H}_{2} \mathrm{O}_{2}$ and $\mathrm{Fm}$ separately on isolated frog heart: Frog ( $R$. tigirina) was pithed by conventional method and the heart was exposed. The pericardium was cut and a pair of threads was passed below the sinus venosus. The distal thread was tied and the proximal thread was made into a loop. After placing a forceps beneath it, a cut was made on the inferior vena cava towards the heart, and Syme's cannula inserted which in turn was connected to a reservoir of frog Ringer solution, and tied tightly with the help of proximal thread. After that, the heart was separated from other tissues and allowed to stabilize for about 10-15 min. ${ }^{[14]}$ Cardiac output, heart rate, and the force of contraction were recorded with increasing concentrations of ACh (10, 30, and 
Figure 1. Effect of acetylcholine and $\mathrm{H}_{2} \mathrm{O}_{2}$ on isolated frog rectus

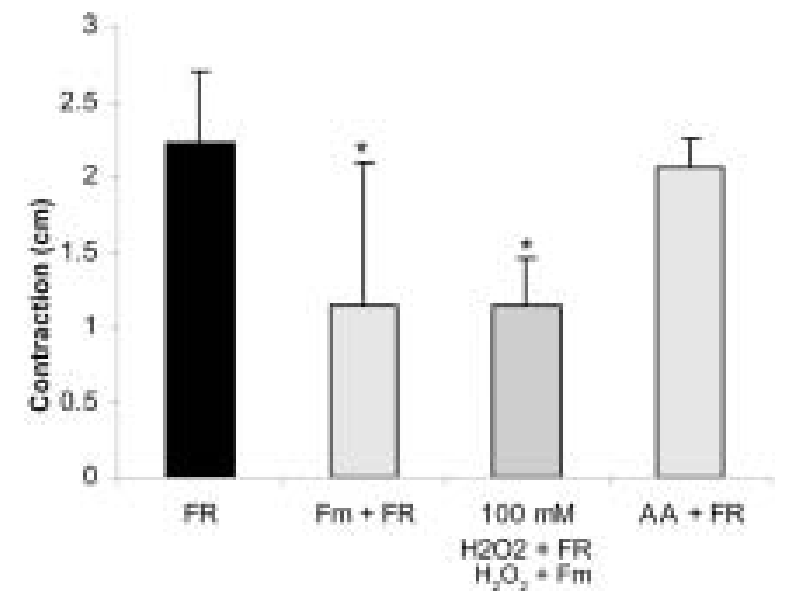

Values are mean \pm SD. $n=6$ in each group. ${ }^{*} P<0.0001$ compared to frog ringer group. FR-frog Ringer; Fm-fenton mixture; AA-ascorbic acid
Figure 2. Effect of ROS on frog rectus abdominis

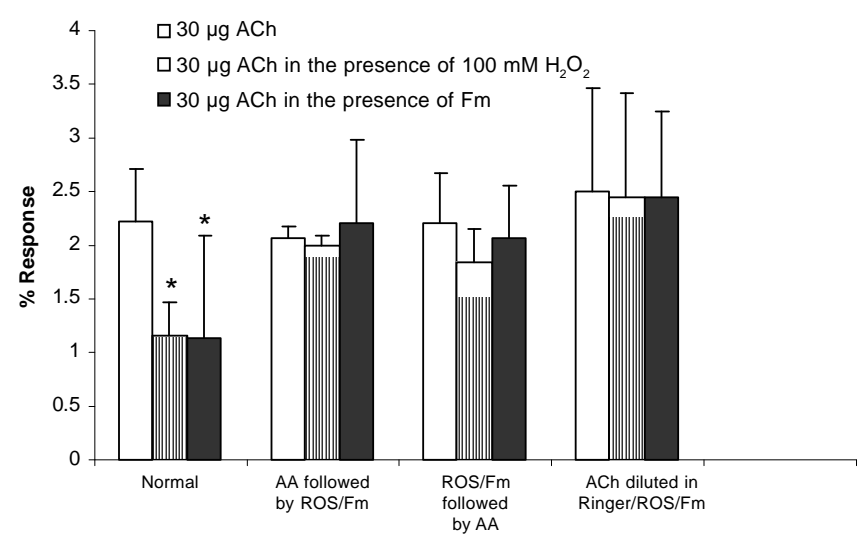

${ }^{*} \mathrm{P}<0.001$, ROS has decreased the response of $\mathrm{ACh}$, when compared with their effect in the presence of normal frog Ringer and AA. ROS had no effect when diluted in ACh. AAAscorbic acid, ROS-Reactive oxygen species, ACh-Acetylcholine and Fm-Fenton mixture

submaximal dose (30 $\mu \mathrm{g})$ was selected. The mean percentage \pm SD of the submaximal response was taken as $100 \%$, which was considered as control. Reduction in the response with Ringer containing $100 \mathrm{mM} \mathrm{H} \mathrm{O}_{2}$ was $48.2 \%(P<0.001)$ compared with the control. The ACh response with frog Ringer containing $100 \mathrm{mM} \mathrm{H}_{2} \mathrm{O}_{2}$ before and after treatment with AA was not changed when compared with the control. There was $48.7 \%$ reduction in ACh response in the presence of $\mathrm{Fm}$ compared $(P<0.001)$ with the control and the ACh response recovered with normal frog Ringer solution [Figure 1]. On pretreatment of FRA with AA, there was no reduction in ACh response with frog Ringer containing Fm. There was no change in ACh response when recorded with ACh prepared in frog Ringer solution, $100 \mathrm{mM} \mathrm{H} \mathrm{H}_{2} \mathrm{O}_{2}$ and Fm separately [Figures 2 and 3].

Effect of $1 \mathrm{mM} \mathrm{H}_{2} \mathrm{O}_{2}$ and Fm separately on muscarinic receptor function

There was a significant $(P<0.001)$ decrease in the force of contraction $(0.7 \pm 0.05)$ and increase in heart rate $(74.3 \pm 9.54)$ in the presence of $1 \mathrm{mM} \mathrm{H}_{2} \mathrm{O}_{2}$ in frog Ringer plus $30 \mathrm{ng}$ ACh as compared to the effect of frog Ringer solution alone or along with $30 \mathrm{ng}$ ACh. However, no significant difference was observed between $1 \mathrm{mM} \mathrm{H}_{2} \mathrm{O}_{2}$ in frog Ringer solution and other parameters. There was a change observed in cardiac output but it was statistically nonsignificant [Table 1 and Figure 4]. There was a similar action with $1 \mathrm{mM} \mathrm{H}_{2} \mathrm{O}_{2}$ on isolated frog heart before and after treatment with AA at $30 \mathrm{ng}$ of ACh when compared with frog Ringer solution alone. There was a significant decrease in the force of contraction and heart rate in frog Ringer solution containing Fm when compared with frog Ringer solution alone. There was a decrease in ACh response (30 ng) in the presence of Fm containing frog Ringer on comparison with ACh response in normal frog Ringer solution. ACh response was reversed on reperfusion with normal frog Ringer solution. On pretreatment of FRA with AA, there was a similar action with Fm on isolated frog heart. There was no change in ACh response when recorded with ACh 
Figure 3. Effect of $100 \mathrm{mM}$ hydrogen peroxide on frog rectus abdominis by using acetylcholine response.

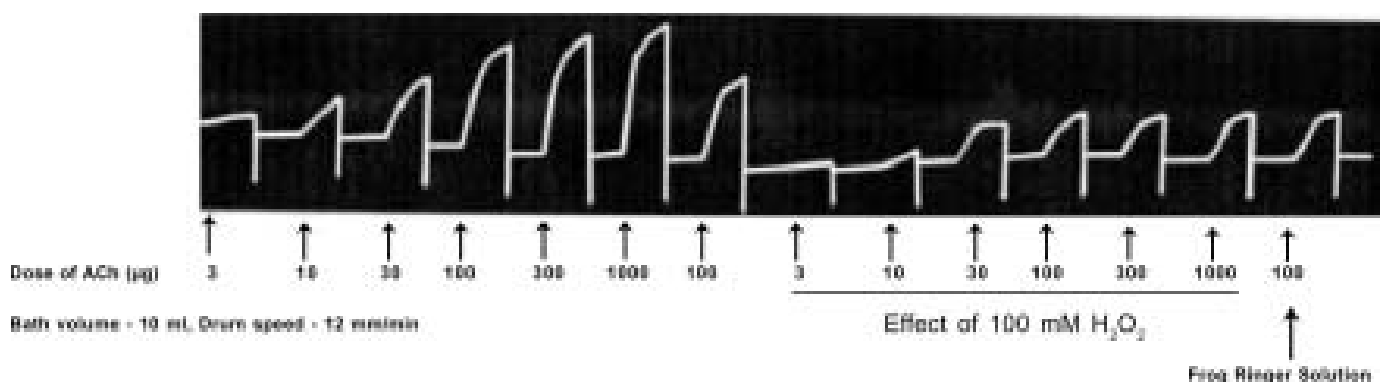

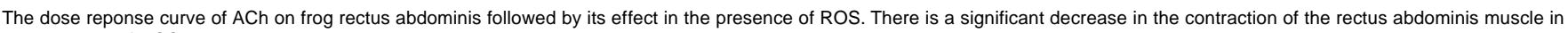
the presence of ROS.

\section{Table 1}

Effect of acetylcholine in the presence of $1 \mathrm{mM} \mathrm{H}_{2} \mathrm{O}_{2}$ on isolated frog heart

\begin{tabular}{lccc}
\hline Parameters & Force of contraction (cm) & Cardiac output (ml/min) & Heart rate/min \\
\hline Frog Ringer & $1.82 \pm 0.09$ & $9.5 \pm 1.23$ & $43.5 \pm 8.45$ \\
Frog Ringer + $30 \mathrm{ng} \mathrm{ACh}$ & $0.1 \pm 0.05$ & $6.4 \pm 1.45$ & $34.9 \pm 6.54$ \\
$1 \mathrm{~mm} \mathrm{H}_{2} \mathrm{O}_{2}$ in frog Ringer & $1.62 \pm 0.08$ & $6.8 \pm 1.89$ & $75.1 \pm 10.21$ \\
$1 \mathrm{~mm} \mathrm{H}_{2} \mathrm{O}_{2}$ in frog Ringer's $+30 \mathrm{ng} \mathrm{ACh}$ & $0.7 \pm 0.05^{*}$ & $6.2 \pm 1.25$ & $74.3 \pm 9.54^{*}$ \\
\hline
\end{tabular}

$\mathrm{n}=6$ in each group. ${ }^{*} \mathrm{P}<0.001$; compared to $30 \mathrm{ng} \mathrm{ACh}$ in frog Ringer

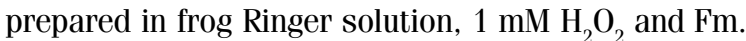

\section{Discussion}

It is clearly evident that free radicals play a pivotal role in the etiology of many diseases. Local free radical formation that occurs under certain pathological conditions, like ischemic reflow, may regulate receptor response. ${ }^{[3]}$ Free radical susceptibility of receptors can be deduced from the presence of functionally critical sulfhydryl group located in the receptor proteins. ${ }^{[15]}$

In the present study, it has been observed that the free radical generation and loss in receptor function were concentration-dependent, which has earlier been reported by Olszewski et al. ${ }^{[16]}$ on trachealis muscle of horse, suggesting that more generation of the free radicals leads to greater receptor damage, which may ultimately result in reduced receptor function. Further, the concentration-dependent effect of ROS was also observed in both the nicotinic receptors of FRA and muscarinic receptors of isolated frog heart, which is thought to be due to the involvement of sulfhydryl groups; it has been proposed for muscarinic cholinergic receptors and detailed molecular delineation of the cysteine residues involved in disulfide bonding of the receptor protein was studied. ${ }^{[15]}$ Ashkenazi et al. reported that ROS potentiate the negative inotropic and attenuate the positive inotropic signalling events in $\mathrm{M}_{2}$ receptor, thereby potentiating the negative inotropic effect of muscarinic receptor agonist (ACh) in isolated rat left atria. These actions of the $\mathrm{M}_{2}$ receptor are thought to be mediated by inducing phospholipase C-mediated phospoinositide turnover. ${ }^{[17]}$
Figure 4. Effect of $1 \mathrm{mM}$ hydrogen peroxide on isolated frog heart by using acetylcholine response

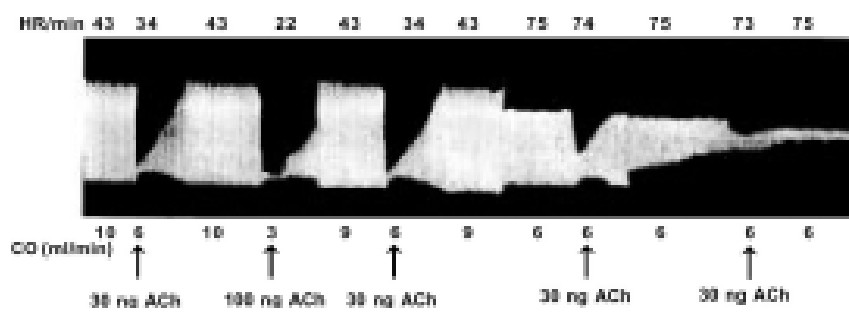

The response of $\mathrm{ACh}$ on isolated frog heart in normal frog Ringer solution followed by its effect with ROS is shown. There is a significant decrease in the force of contraction of the heart and increased in heart rate.

Doleman et al., in 1988 reported the antioxidant effect of vitamin $\mathrm{E}$ and selenium in lung tissue after exposure to $\operatorname{ROS}^{[18]}$ and Mangelus et al., in 2001 also reported that the Ras, extra cellular signal-regulated kinase and p38 are responsible for the imbalance which is brought about by muscarinic activation. These pathways were blocked by the antioxidant Nacetylcysteine when exposed to ROS..$^{[9]}$ In the present study on pretreatment of frog's rectus abdominis with AA, there was no reduction in ACh response with frog Ringer containing ROS. It is further evident that there is no effect of ROS on nicotinic receptor function on prior exposure to antioxidants (AA). In contrast, AA has not shown any beneficial effect on the muscarinic receptor site. The study on exposure of antioxidants after treatment with ROS showed that the receptor activity has been reversed in the nicotinic receptor in contrast to the 
muscarinic receptor, which may be due to permanent loss of muscarinic receptor activity. This again implies that the muscarinic receptors are more susceptible to free radicals than the nicotinic receptors. It may be attributed to the sulfhydryl groups of the G-protein-coupled muscarinic receptors, which are more susceptible and sensitive to ROS than the ionchannel-linked nicotinic receptors.

The investigation also reveals that, with increase in exposure time (10-30 min) of ROS at the receptor site, there is a corresponding decrease in receptor activity even at a higher dose of ACh $(300 \mu \mathrm{g})$. This clearly indicates that effective free radical attack is time dependent. The time-dependent effect of ROS was observed both in nicotinic and muscarinic receptors. The effect of ACh was reduced with very low concentration of ROS $\left(1 \mathrm{mM} \mathrm{H} \mathrm{H}_{2}, 1: 50 \mathrm{Fm}\right)$ on muscarinic receptors, compared to that on nicotinic receptors $\left(0.1 \mathrm{M} \mathrm{H}_{2} \mathrm{O}_{2}\right.$ or 3:50 Fm). This also indicates that the muscarinic receptors are more sensitive to ROS than nicotinic receptors.

Reactive oxygen species has shown different effects on receptor function. The actions of Fm were reversed both in nicotinic and muscarinic receptors when replacing with normal frog Ringer's solution but not with $\mathrm{H}_{2} \mathrm{O}_{2}$. This indicates that $\mathrm{H}_{2} \mathrm{O}_{2}$ causes permanent damage at the receptor site. ACh diluted in Fm and $\mathrm{H}_{2} \mathrm{O}_{2}$ showed no change in ACh response, which indicates that the effect of ROS was due to altered receptor function but not due to chemical alteration of ACh or in vitro interaction.

\section{Conclusion}

From the above study, it is clear that free radicals cause damage to the receptors. G-protein-coupled muscarinic receptors are more susceptible than ion-channel-linked nicotinic receptors. Ascorbic acid, a free radical scavenger, offers protection from ROS at the receptor site. A thorough and detailed investigation had been planned to support the study.

\section{Acknowledgments}

The first author is thankful to the University Grants Commission (UGC), New Delhi, for providing financial assistance in carrying out the work.

\section{References}

1. Kenakin TP, Bond RA, Bonner TI. Definition of pharmacological receptors.
Pharmacol Rev 1992;44:351-62.

2. Peters SL, Sand C, Batinik HD, Pfaffendorf M, Van Zwieten PA. Reactive oxygen species potenciate the negative inotropic effect of cardiac M Muscarinic receptor stimulation. Naunyn Schmiedebergs Arch Pharmacol. 2001;364:166-71.

3. Bast A, Haenen GR. Receptor function in free radical mediated pathologies. In: Trends in drug research. V. Classen, editor. Vol. 13, 1990. p. 273-85.

4. Halliwell B, Gutteridge JM, Cross CE. Free radicals, antioxidants and human disease: where are we now? J Lab Clin Med 1992;119:598-620.

5. Ross EM, Kenakin TP. Pharmacodynamics. In: Goodman \& Gilman's. The pharmacological basis of therapeutics. Hardman JG, Limbird LE, Molinoff PB, Ruddon RW, Gilman AG, editors. $10^{\text {th }}$ ed. New York: Mc Graw Hill; 2001. p 367.

6. Taylor P. Anticholinesterase agents. In: Goodman \& Gilman's. The pharmacological basis of therapeutics. Hardman JG, Limbird LE, Molinoff PB, Ruddon RW, Gilman AG, editors. 10 $0^{\text {th }}$ ed. New York: Mc Graw Hill; 2001. p 187-8.

7. Hoffman BB, Taylor P. Neurotransmission. In: Goodman \& Gilman's. The pharmacological basis of therapeutics. Hardman JG, Limbird LE, Molinoff PB, Ruddon RW, Gilman AG, editors. 10 $0^{\text {th }}$ ed. New York: Mc Graw Hill; 2001. p 138-43.

8. Peters SL, Batink HD, Michel MC, Pfaffendorf M, van Zwieten PA. Possible mechanism of the negative inotropic effect of alpha-adrenoceptor agonists in rat isolated left atria after exposure to free radicals. $\mathrm{Br} \mathrm{J}$ Pharmacol 1998;123:952-8.

9. Mangelus M, Kroyter A, Galron R, Sokolovsky M. Reactive oxygen species regulate signaling pathways induced by $\mathrm{M}$ muscarinic receptors in PC12M1 cells. J Neurochem 2001;76:1701-11.

10. Arora RC, Hess ML. Effect of reduced oxygen intermediates on sarcolemmal muscarinic receptors from canine heart. Biochem Biophys Res Commun 1985; 130:133-40.

11. Merli C, Petrucci E, Da Pozzo A, Pernetti M. Fenton-type treatment: state of the art. Ann Chim 2003;93:761-70.

12. Ghosh MN. Some standard drugs and chemicals. In: Fundamentals of experimental pharmacology. $2^{\text {nd }}$ ed. Calcutta: Scientific book agency; 1984.

13. Kulkarni SK. Experiments on isolated preparations. In: Hand book of experimental pharmacology. $3{ }^{\text {rd }}$ ed. Delhi: Vallabh Prakashan; 1999.

14. Kulkarni SK. Pharmacology of cardiovascular system. In: Hand book of experimental pharmacology. $3^{\text {rd }}$ ed. Delhi: Vallabh Prakashan; 1999.

15. Aronstam RS, Abood LG, Hoss W. Influence of sulfhydryl reagents and heavy metals on the functional state of the muscarinic acetylcholine receptors in rat brain. Mol Pharmacol 1978;14:575-80.

16. Olszewski MA, Robinson NE, Yu MF, Derksen FJ. Effect of hydrogen peroxide on isolated trachealis muscle of horse. Am J Vet Res 1995;56:1479-85.

17. Ashkenazi A, Winslow JW, Peralta EG, Peterson GL, Schimerlik MI, Capon DJ, et al. An M2 muscarinic receptor subtype coupled to both adenylyl cyclase and phosphoinositide turnover. Science 1987;238:672-5.

18. Doleman CJ, Kramer K, Timmerman H, Bast A. Vitamin E and selenium regulate balance between beta adrenergic and muscarinic responses in rat lungs. FEBS Lett 1988;233:427-31.

\section{Join "IndPharm" \\ IJP uses "IndPharm" to broadcast announcements. Want to join? Please E-mail: adithan@vsnl.com}

